\title{
Model of Minimum CBR Distance Travelled by packets in MANETs using Location-Aware Transmission for Ubicomp.
}

\author{
M. Kaleem GALAMALI, Assoc. Prof Nawaz MOHAMUDALLY
}

\begin{abstract}
Management of energy consumption of nodes in ubicomp can be assisted by location-aware transmission strategies in MANETs [63]. Hence researchers believe that further development in location-aware transmission in MANETs must be undertaken. It is projected that further development will involve technologies like Landbased GPS systems, improved location refresh rates and location accuracy, along with developments of better protocols optimised for transmission following distance criteria. To enable proper tuning of transmission protocols or even to select appropriate protocols, and achieve optimal MANET performance, the applicability of known trends of distance coverages by packets in a ubicomp for varying node density remain considerable.
\end{abstract}

Two previous studies in this direction were made whereby two metrics were developed and their trend analyses put forward: PPD [26] and Max_CBR_Dist [27] which is derived from PPD.

This paper adds a third component after the metric PPD and Max_CBR_Dist to the area of modelling for managing distance packets travel in ubicomp topography of varying node densities. Designers may use these results towards formulation of better transmission protocols for ubicomp. This piece of research is a follow-up of previous work [1-27].

Key terms: Ubicomp- Ubiquitous Computing, MAUCMobile and Ubiquitous Computing, MANET- Mobile Adhoc Network, PPD- Packets_Per_Distance, Max_CBR_Dist- Maximum CBR Distance, Min_CBR_Dist- Minimum_CBR_Distance, CBRConstant Bit Rate.

M. Kaleem GALAMALI,

University of Technology Mauritius (student) Mauritius

Assoc. Prof Nawaz Mohamudally University of Technology Mauritius, Mauritius

\section{Introduction}

Energy consumption in MAUC is predominantly affected by distance coverages. The effect of distance of transmission is very consequent since energy consumption varies proportional to the square of distance coverages by packets [15]. Using MANET strategy of transmission, the sender node along with all MANET route nodes forward packets corresponding to each CBR. A considerable impact in the ubicomp topography is that total number of packets in circulation increases with increasing node density. The sender sends packets to its closest neighbour which in turn forwards the packets to its closest "yet unused" neighbour. Nodes are mobile here, and hence in the dynamic topology changes occurring, there is no guarantee that all hops will be of equal distance nor that the first hop is the smallest or biggest one for each CBR. The research questions forwarded here are: "What are the minimum hop distance experienced by each CBR? What is the trend observable for this minimum hop count and how does it vary with varying node densities?"

The work presented here, remains empirical based and is built over previous work [26, 27]. It follows from the statement that metric PPD is a wide scope metric from which other sub-component metrics could be formulated. Each such sub-component metric may have specific characteristics that may be utilised for specific decision making in protocols to be used and also drive research for refinement of relevant sections in the transmission protocols.

The key contributions of this paper is firstly, the development of a second derived metric Min_CBR_Dist, derived from PPD for CBR Packet Per Distance analyses. The definition and rationale of metric Min_CBR_Dist is put forward. Secondly, the model of trend is put forward for the metric Min_CBR_Dist with results for varying node densities from 7 until 56 in a topography of $300 \times 300 \mathrm{~m}^{2}$. The plot for cumulative tendency for the metric Min_CBR_Dist give more observable trend. The model proposed is the increasing exponential model. The rest of this paper is organised as follows: section 2- New Derived Metric - Minimum_CBR_Distance, section 3Min_CBR_Dist Trend Assessment over Varying Node Numbers, 4- Conclusion and References.

\section{New Derived Metric - Minimum_CBR_Distance.}

Following definition of PPD [26], Min_CBR_Dist is defined as the minimum distance coverage noted for the whole of a CBR along a MANET topography. It can also be termed as the shortest hop distance noted for a CBR. 
Proc. of Sixth International Conference On Advances in Computing, Electronics and Electrical Technology - CEET 2016 Copyright (C Institute of Research Engineers and Doctors. All rights reserved.

ISBN no. 978-1-63248-109-2 doi: 10.15224/ 978-1-63248-109-2-10

MANET routes may vary during a CBR transmission. Here also, it is envisageable that value 0 for the metric Min_CBR_Dist may be obtained. It would mean that the hop distance is between 0.00 and below $0.50 \mathrm{~m}$.

The results of this study may serve towards the same purposes as described in previous paper [26].

\section{Min_CBR_Dist - Trend Assessment over Varying Node Numbers.}

3.0 Major Observations.

Plotting \% CBR against Min_CBR_Dist values depict sparse distribution of plots whereby trend is unconvincing as depicted for node number 7 in figure 1(a). The plot for cumulative \% CBR against Min_CBR_Dist shows much better observable trends.

Overall, the trend observable is a rapid increase from origin, followed by a flattening of the curve till reaching the $100 \% \mathrm{y}$-axis value. The equation of the curve is:

$$
F(x)=a * \exp (b *(x-c))+d
$$

\subsection{Tabular Summary of Results.}

A tabular summary for results of equations of curves $(\mathrm{F}(\mathrm{x}))$ is shown below. Column headings are: $\mathrm{A} \rightarrow$ node number, $\mathrm{B} \rightarrow$ Value of parameter $\mathrm{a}, \mathrm{C} \rightarrow$ Value of parameter $\mathrm{b}, \mathrm{D} \rightarrow$ value of parameter $\mathrm{c}, \mathrm{E} \rightarrow$ value of parameter $\mathrm{d}, \mathrm{F} \rightarrow$ reduced chi-square value of plot $\mathrm{F}(\mathrm{x})$, $\mathrm{G} \rightarrow$ Corresponding figure number.

\begin{tabular}{|c|c|c|c|c|c|c|}
\hline A & B & C & D & $\mathbf{E}$ & $\mathbf{F}$ & G \\
\hline 7 & -164.88 & 0.0307049 & -99.6084 & 99.8639 & 0.0230836 & 1(b) \\
\hline 8 & -121.654 & 0.0137897 & -232.028 & 100.89 & 0.0090967 & 2 \\
\hline 9 & -138.623 & -0.0176515 & -199.515 & 100.379 & 0.00996331 & 3 \\
\hline 10 & -160.461 & 0.0277389 & -122.405 & 101.174 & 0.0301482 & 4 \\
\hline 11 & -160.461 & 0.0277389 & -122.405 & 101.174 & 0.0301482 & 5 \\
\hline 12 & -157.488 & -0.0250142 & -135.432 & 101.342 & 0.0247586 & 6 \\
\hline 13 & -162.673 & 0.0348097 & -113.377 & 100.488 & 0.0128537 & 7 \\
\hline 14 & -161.784 & 0.0332653 & -118.398 & 100.537 & 0.0112392 & 8 \\
\hline 15 & -163.187 & 0.0357444 & -110.35 & 100.466 & 0.00914971 & 9 \\
\hline 16 & -164.572 & -0.0392509 & -101.837 & 100.346 & 0.00545878 & 10 \\
\hline 17 & -166.845 & 0.0405324 & -87.5943 & 101.346 & 0.0282786 & 11 \\
\hline 18 & -167.173 & 0.0421454 & 85.2718 & 101.215 & 0.0196547 & 12 \\
\hline 19 & -167.133 & 0.0417669 & 85.6162 & 101.26 & 0.0202041 & 13 \\
\hline 20 & -167.416 & -0.0428213 & 83.6859 & 101.21 & 0.019129 & 14 \\
\hline 21 & -168.74 & 0.0544579 & -71.5948 & 100.564 & 0.0226032 & 15 \\
\hline 22 & -168.763 & -0.0555399 & -70.9855 & 100.508 & 0.0184988 & 16 \\
\hline 23 & -168.183 & 0.0522563 & -75.7326 & 100.557 & 0.0204997 & 17 \\
\hline 24 & -168.528 & 0.054324 & -72.8666 & 100.521 & 0.0175692 & 18 \\
\hline 25 & -169.094 & 0.0587563 & -67.7462 & 100.433 & 0.0137952 & 19 \\
\hline 26 & -167.496 & 0.0455579 & 82.2601 & 100.98 & 0.0154015 & 20 \\
\hline 27 & -166.44 & 0.0415901 & -89.7036 & 101.118 & 0.0174188 & 21 \\
\hline 28 & -166.059 & 0.0400715 & 92.3017 & 101.214 & 0.0246998 & 22 \\
\hline 29 & -167.174 & -0.0435408 & -84.8075 & 101.102 & 0.0205505 & 23 \\
\hline 30 & -167.429 & 0.0454326 & 82.6953 & 100.97 & 0.0203138 & 24 \\
\hline 31 & -171.721 & 0.0897014 & -43.382 & 100.258 & 0.011023 & 25 \\
\hline 32 & -171.552 & 0.0885348 & 44.3209 & 100.251 & 0.00817885 & 26 \\
\hline 33 & -171.411 & 0.086255 & -45.5983 & 100.27 & 0.00886624 & 27 \\
\hline 34 & -171.411 & 0.086255 & 45.5983 & 100.27 & 0.00886624 & 28 \\
\hline 35 & -171.61 & 0.0892006 & -43.9028 & 100.251 & 0.0123703 & 29 \\
\hline 36 & -171.697 & -0.0896411 & -43.4741 & 100.254 & 0.00878412 & 30 \\
\hline
\end{tabular}

\begin{tabular}{|l|l|l|l|l|l|l|}
\hline 37 & -171.355 & -0.109151 & -38.6643 & 100.128 & 0.0120413 & 31 \\
\hline 38 & -171.355 & -0.109151 & -38.6657 & 100.128 & 0.0120375 & 32 \\
\hline 39 & -171.149 & -0.10402 & -40.6665 & 100.156 & 0.0150963 & 33 \\
\hline 40 & -171.1320621 & -0.104933 & -40.463739 & 100.143 & 0.0126643 & 34 \\
\hline 41 & -170.915 & -0.0998614 & -42.8196 & 100.163 & 0.0137197 & 35 \\
\hline 42 & -171.137 & -0.112748 & -38.2752 & 100.076 & 0.0118727 & 36 \\
\hline 43 & -171.037 & -0.153615 & -30.2293 & 99.9487 & 0.00378911 & 37 \\
\hline 44 & -171.038 & -0.153615 & -30.2252 & 99.9486 & 0.00379392 & 38 \\
\hline 45 & -170.817 & -0.138435 & -33.8185 & 99.9685 & 0.00362721 & 39 \\
\hline 46 & -170.817 & -0.138435 & -33.8185 & 99.9685 & 0.00362721 & 40 \\
\hline 47 & -170.872 & -0.144242 & -32.4701 & 99.9576 & 0.00405907 & 41 \\
\hline 48 & -171.044 & -0.170249 & -27.5397 & 99.9276 & 0.0050744 & 42 \\
\hline 49 & -171.012 & -0.187778 & -25.3093 & 99.9064 & 0.0059446 & 43 \\
\hline 50 & -169.923 & -0.114909 & -43.7101 & 100.088 & 0.00298951 & 44 \\
\hline 51 & -169.923 & -0.114909 & -43.7101 & 100.088 & 0.00298951 & 45 \\
\hline 52 & -169.631 & -0.104032 & -48.3736 & 100.116 & 0.0034827 & 46 \\
\hline 53 & -169.923 & -0.114909 & -43.7101 & 100.088 & 0.00298951 & 47 \\
\hline 54 & -169.75 & -0.114836 & -44.7429 & 100.066 & 0.00174002 & 48 \\
\hline 55 & -169.387 & -0.0987216 & -51.4648 & 100.119 & 0.00403325 & 49 \\
\hline 56 & -169.387 & -0.0987216 & -51.4648 & 100.119 & 0.00403325 & 50 \\
\hline
\end{tabular}

Table 1: summary of results for Min_CBR_Dist equations of curves node numbers 7-56

\subsection{Graphical Plots for Results Obtained.}

This analysis is performed in gnuplot in Linux. $\mathrm{x}$-axis distance is in meters.

\section{Node Number 7}

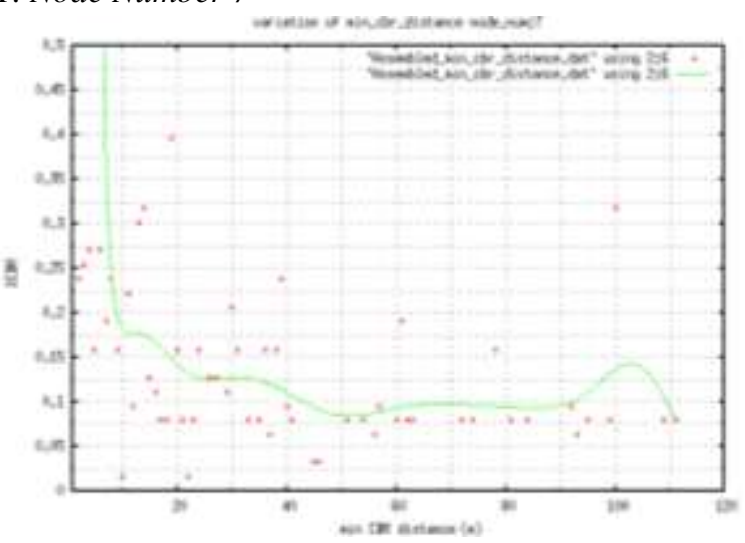

Figure 1(a): \% CBR against min_CBR_distance : node_num 7

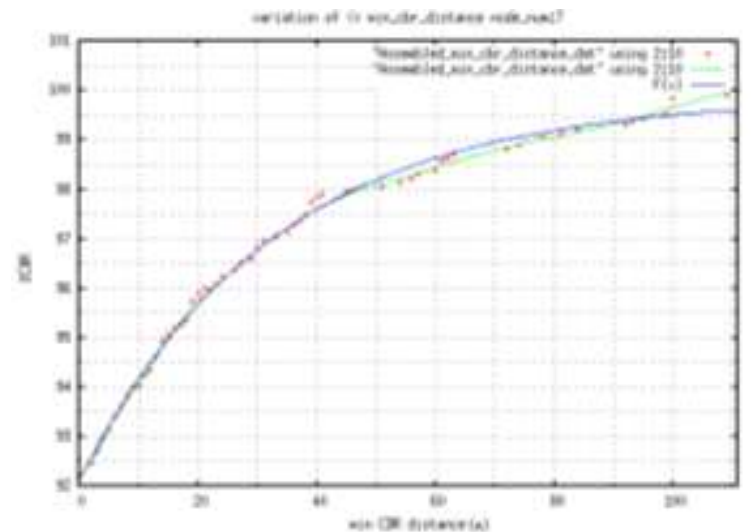

Figure 1(b): \% CBR $\leq$ min_CBR_distance : node_number 7 2. Node Number 8 
Proc. of Sixth International Conference On Advances in Computing, Electronics and Electrical Technology - CEET 2016 Copyright (C) Institute of Research Engineers and Doctors. All rights reserved.

ISBN no. 978-1-63248-109-2 doi: 10.15224/ 978-1-63248-109-2-10

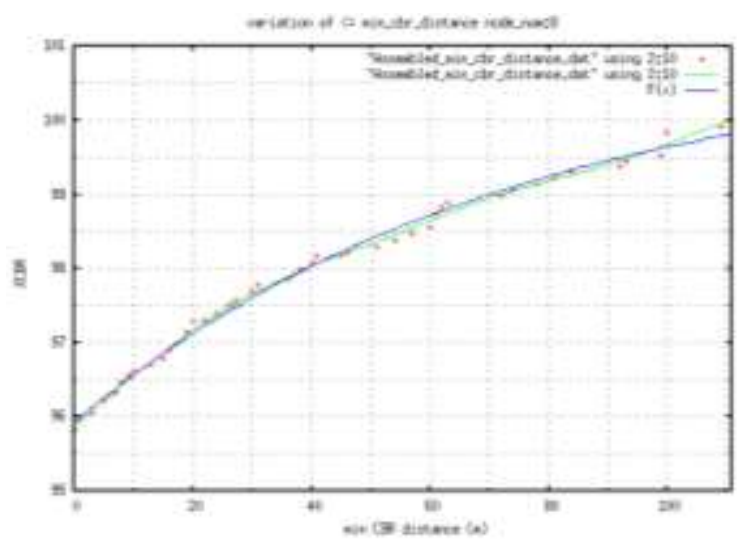

Figure 2: \% CBR $\leq$ min_CBR_distance: node_num 8 3. Node Number 9

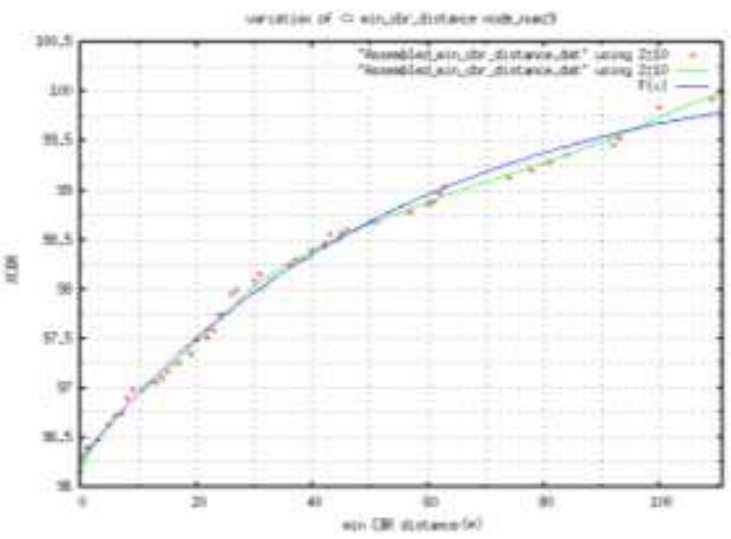

Figure 3: \% CBR $\leq$ min_CBR_distance: node_num 9 4. Node Number 10

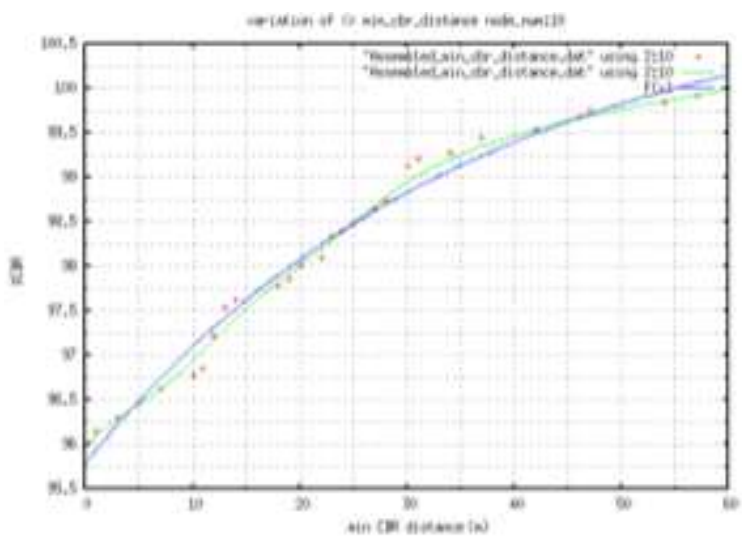

Figure 4: \% CBR $\leq$ min_CBR_distance: node_num 10 5. Node Number 11

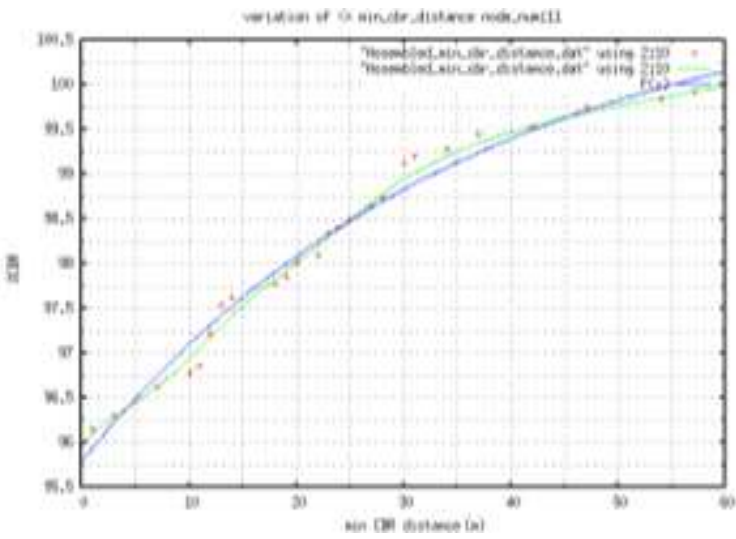

Figure 5: \% CBR $\leq$ min_CBR_distance: node_num 11 6. Node Number 12

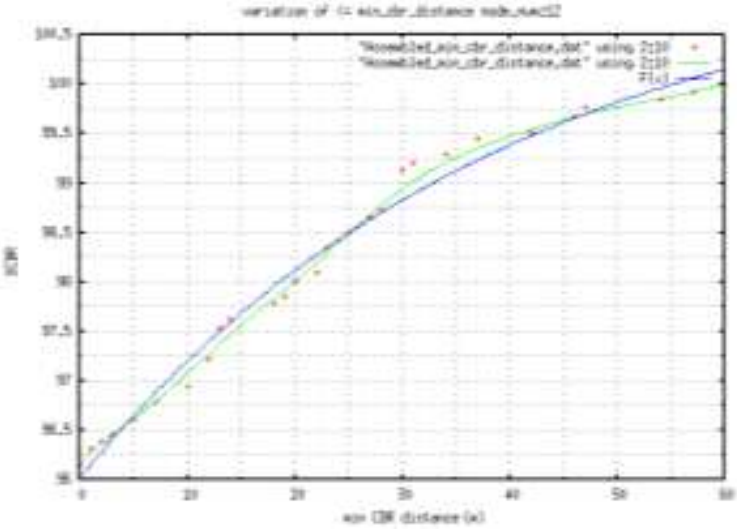

Figure 6: \% CBR $\leq$ min_CBR_distance: node_num 12

7. Node Number 13

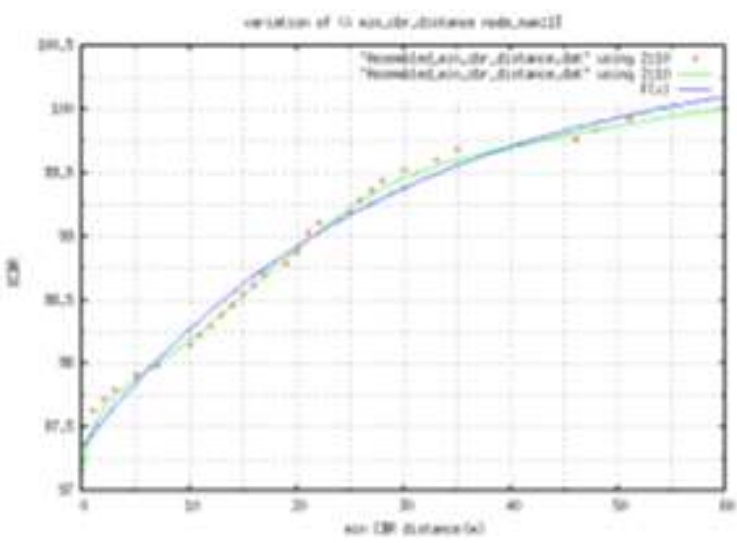

Figure 7: \% CBR $\leq$ min_CBR_distance: node_num 13

8. Node Number 14

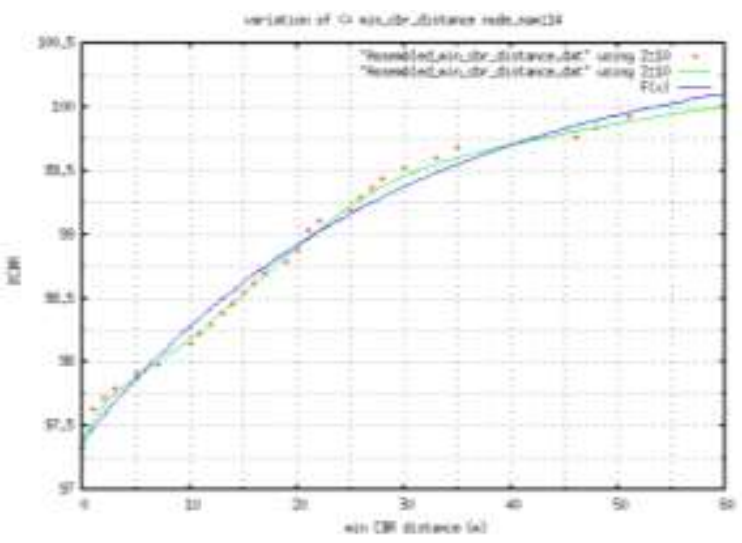

Figure 8: \% CBR $\leq$ min_CBR_distance: node_num 14

9. Node Number 15

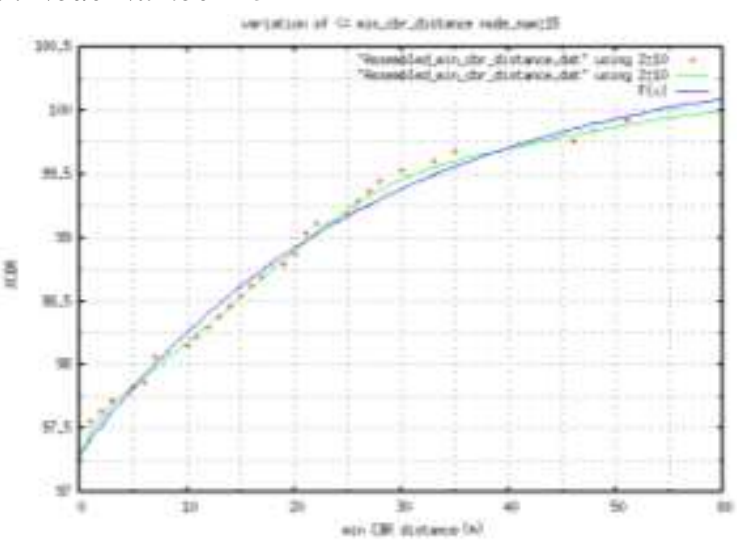

Figure 9: \% CBR $\leq$ min_CBR_distance: node_num 15 10. Node Number 16 
Proc. of Sixth International Conference On Advances in Computing, Electronics and Electrical Technology - CEET 2016 Copyright (C) Institute of Research Engineers and Doctors. All rights reserved.

ISBN no. 978-1-63248-109-2 doi: 10.15224/ 978-1-63248-109-2-10

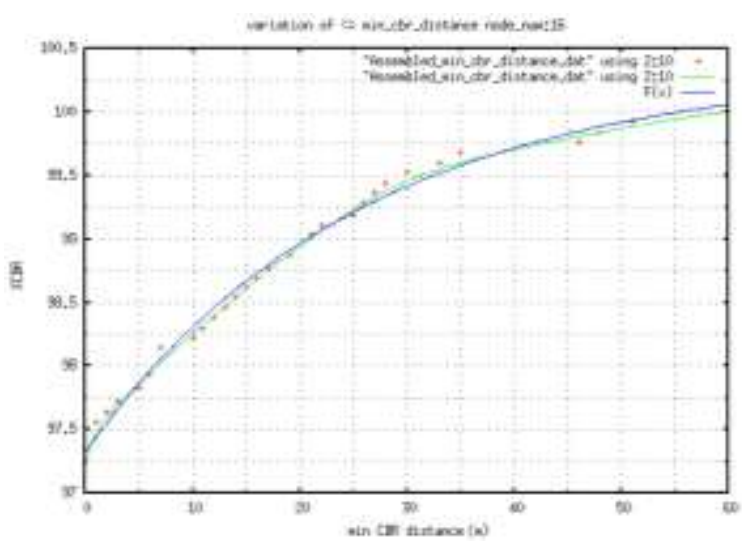

Figure 10: \% CBR $\leq$ min_CBR_distance: node_num 16 11. Node Number 17

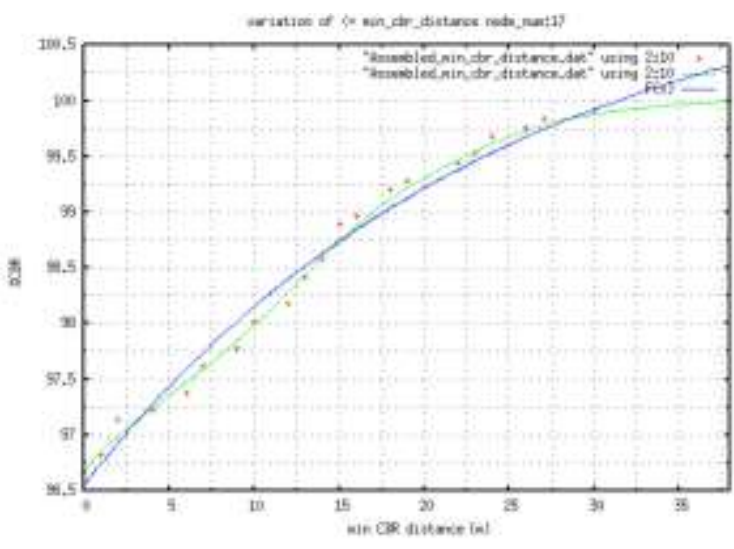

Figure 11: \% CBR $\leq$ min_CBR_distance: node_num 17 12. Node Number 18

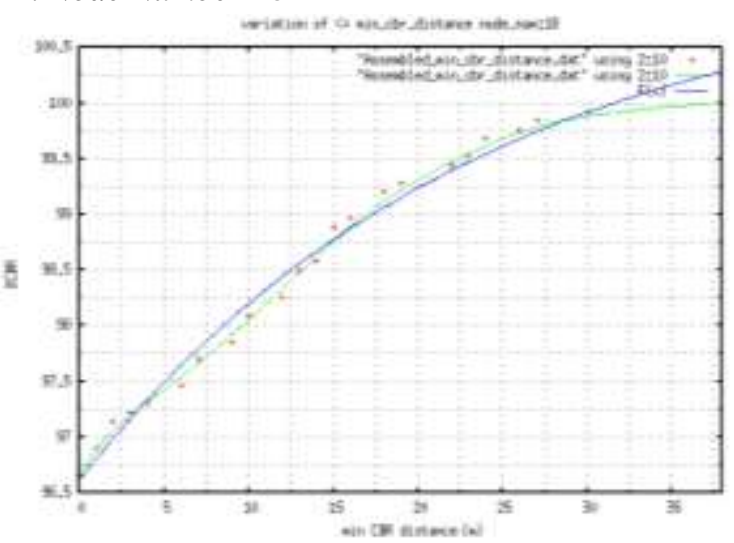

Figure 12: \% CBR $\leq$ min_CBR_distance: node_num 18 13. Node Number 19

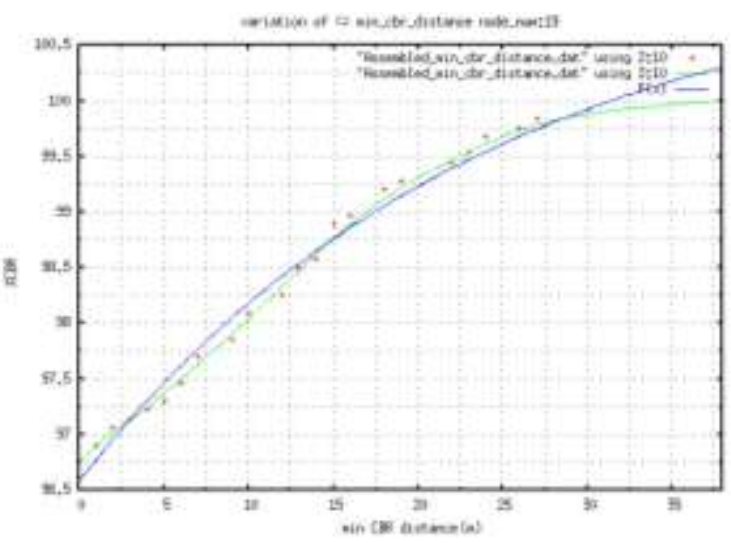

Figure 13: \% CBR $\leq$ min_CBR_distance: node_num 19 14. Node Number 20

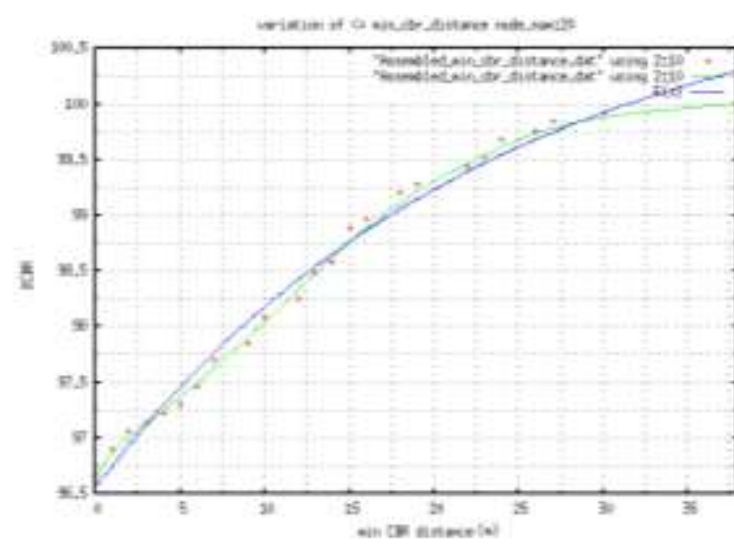

Figure 14: \% CBR $\leq$ min_CBR_distance: node_num 20 15. Node Number 21

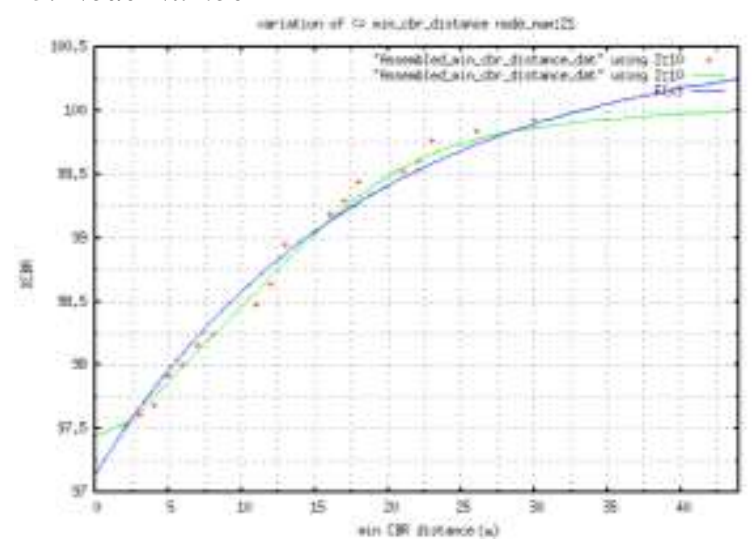

Figure 15: \% CBR $\leq$ min_CBR_distance: node_num 21 16. Node Number 22

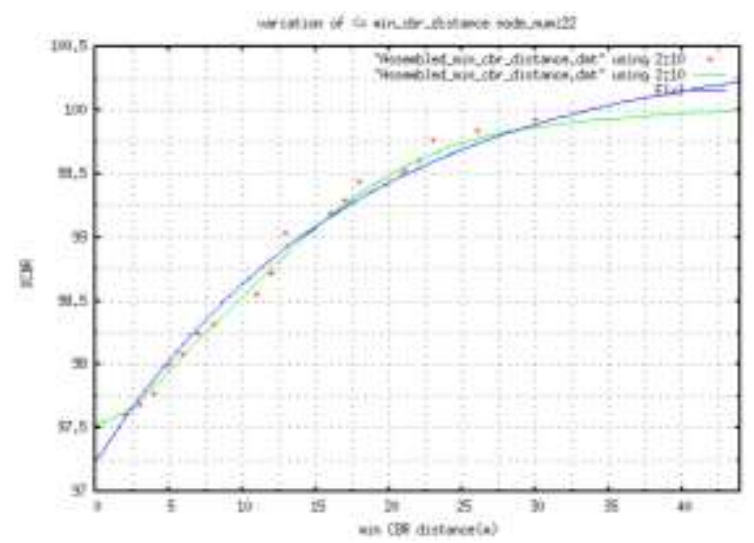

Figure 16: \% CBR $\leq$ min_CBR_distance: node_num 22 17. Node Number 23

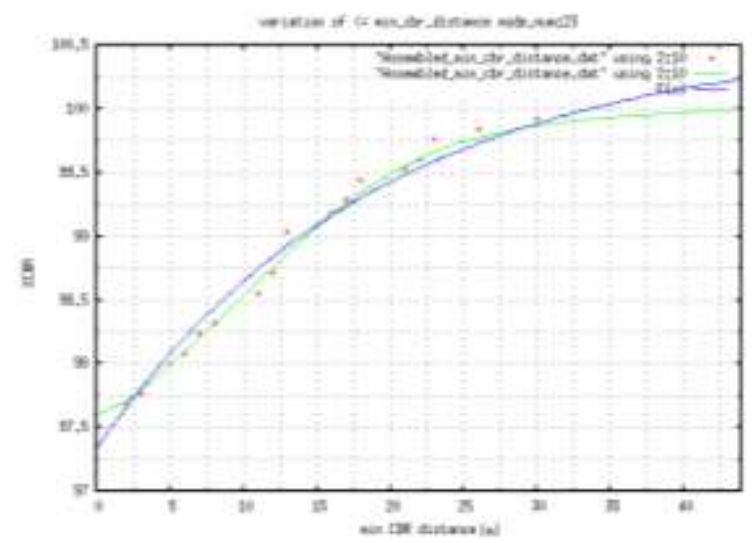

Figure 17: \% CBR $\leq$ min_CBR_distance: node_num 23 18. Node Number 24 
Proc. of Sixth International Conference On Advances in Computing, Electronics and Electrical Technology - CEET 2016 Copyright (C) Institute of Research Engineers and Doctors. All rights reserved.

ISBN no. 978-1-63248-109-2 doi: 10.15224/ 978-1-63248-109-2-10

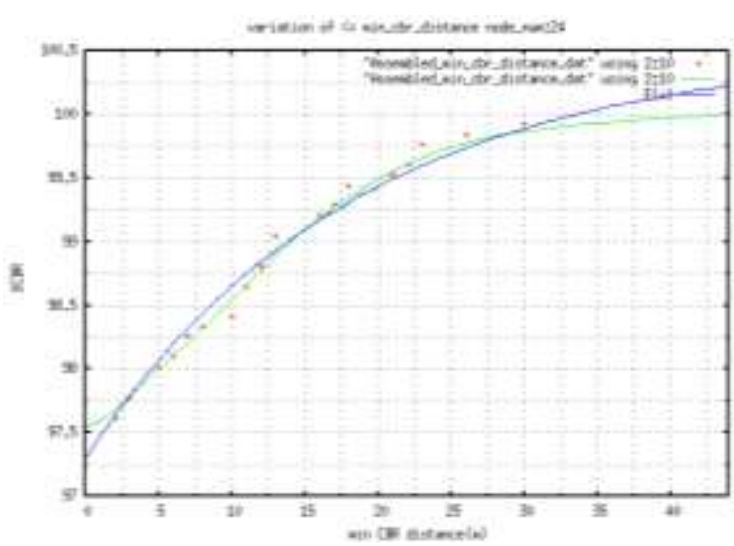

Figure 18: \% CBR $\leq$ min_CBR_distance: node_num 24 19. Node Number 25

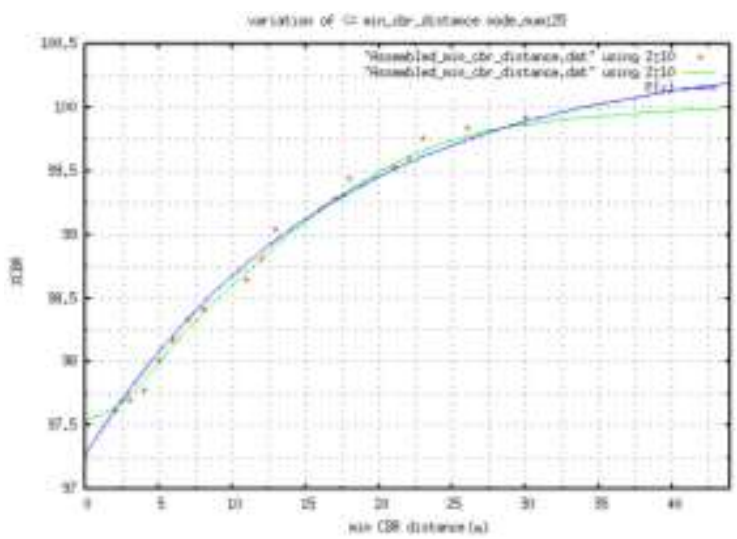

Figure 19: \% CBR $\leq$ min_CBR_distance: node_num 25 20. Node Number 26

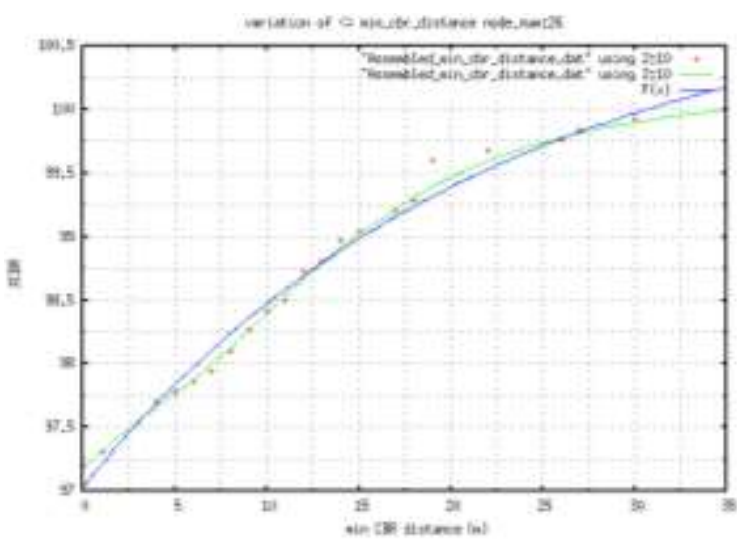

Figure 20: \% CBR $\leq$ min_CBR_distance: node_num 26 21. Node Number 27

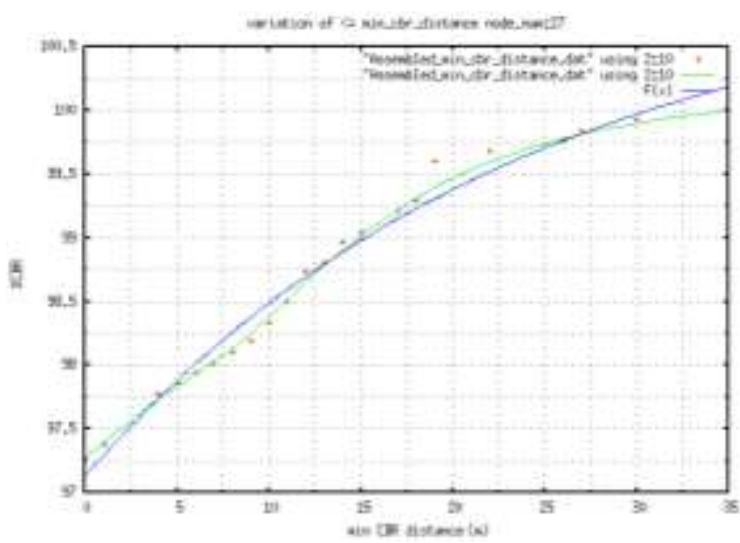

Figure 21: \% CBR $\leq$ min_CBR_distance: node_num 27 22. Node Number 28

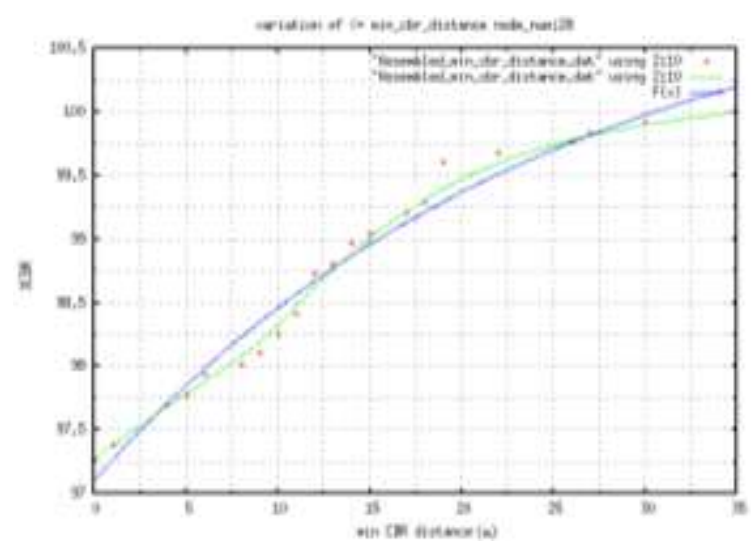

Figure 22: \% CBR $\leq$ min_CBR_distance: node_num 28 23. Node Number 29

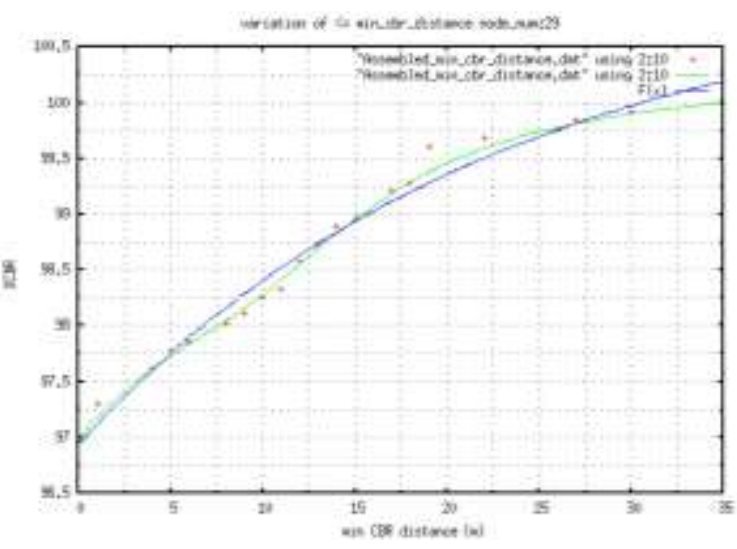

Figure 23: \% CBR $\leq$ min_CBR_distance: node_num 29

24. Node Number 30

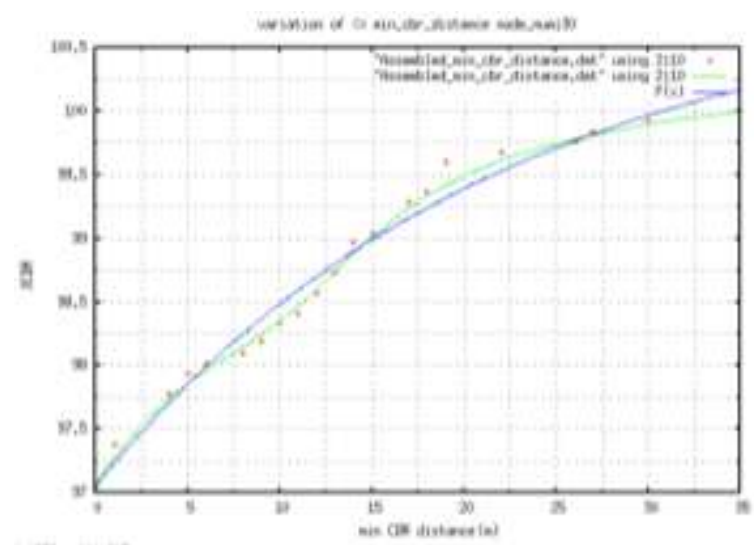

Figure 24: \% CBR $\leq$ min_CBR_distance: node_num 30 25. Node Number 31

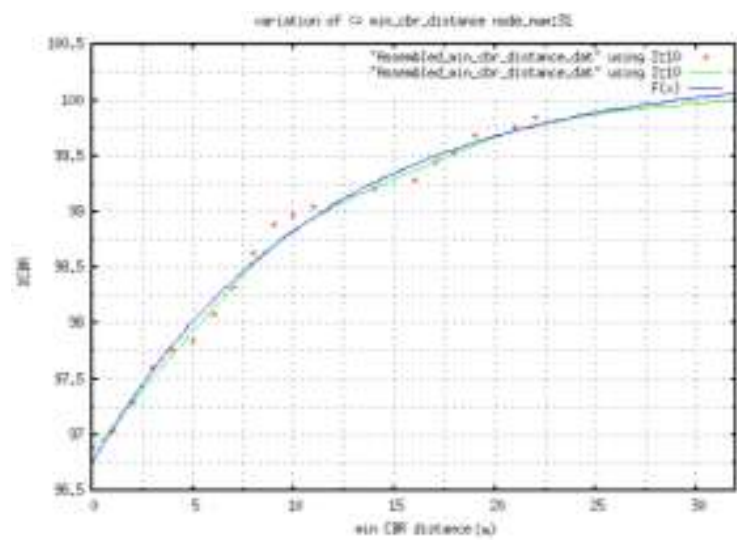

Figure 25: \% CBR $\leq$ min_CBR_distance: node_num 31 26. Node Number 32 
Proc. of Sixth International Conference On Advances in Computing, Electronics and Electrical Technology - CEET 2016 Copyright (C) Institute of Research Engineers and Doctors. All rights reserved.

ISBN no. 978-1-63248-109-2 doi: 10.15224/ 978-1-63248-109-2-10

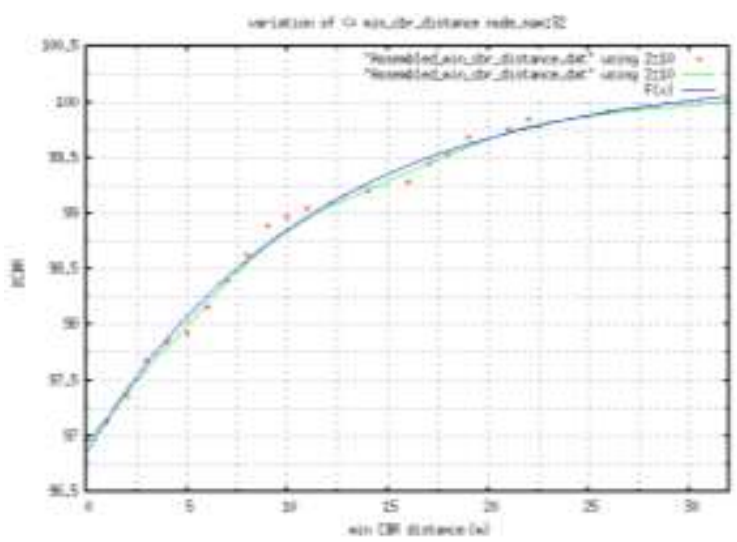

Figure 26: \% CBR $\leq$ min_CBR_distance: node_num 32 27. Node Number 33

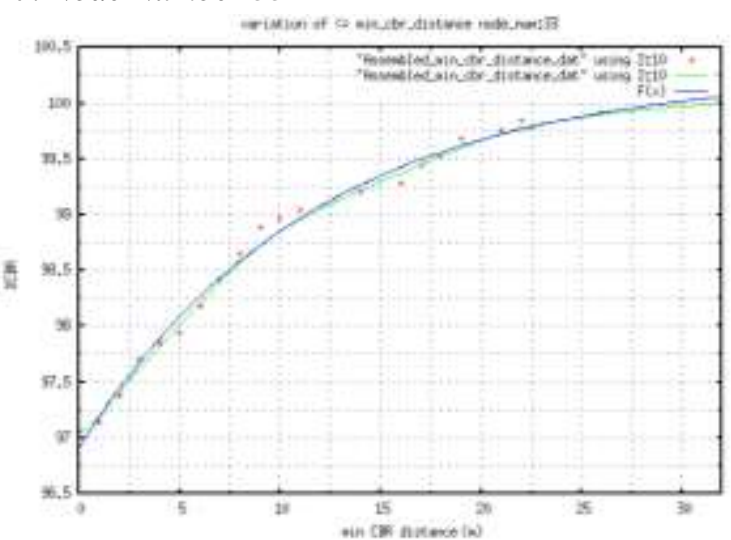

Figure 27: \% CBR $\leq$ min_CBR_distance: node_num 33 28. Node Number 34

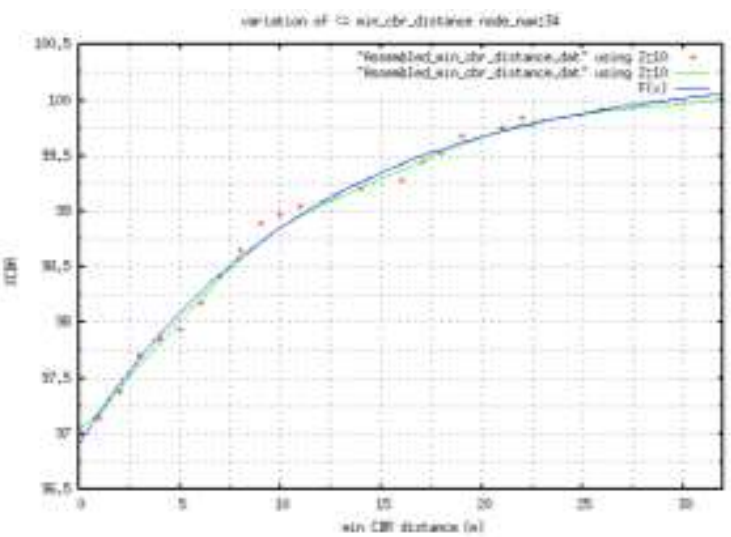

Figure 28: \% CBR $\leq$ min_CBR_distance: node_num 34 29. Node Number 35

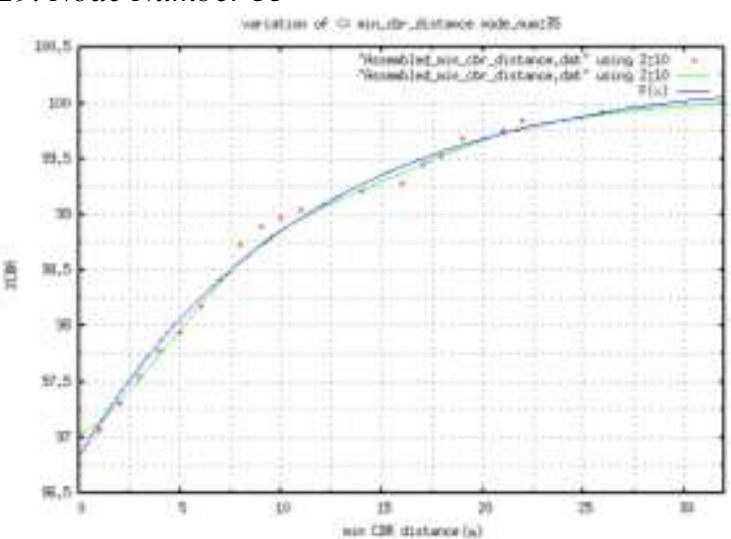

Figure 29: \% CBR $\leq$ min_CBR_distance: node_num 35 30. Node Number 36

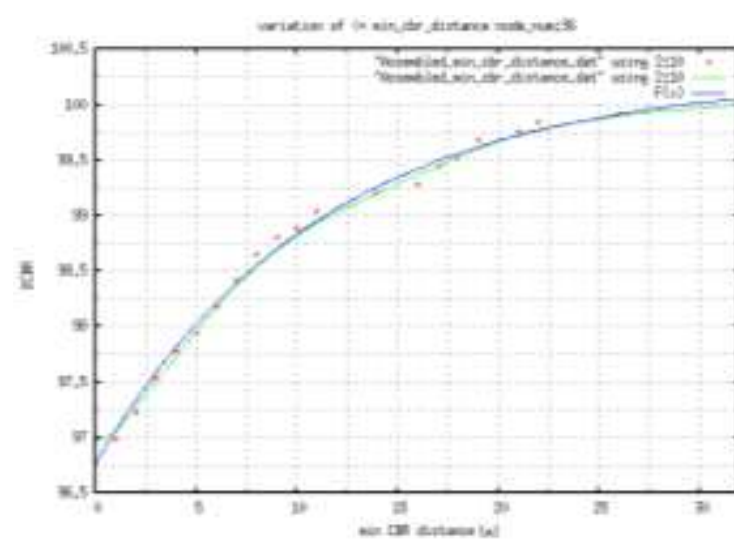

Figure 30: \% CBR $\leq$ min_CBR_distance: node_num 36 31. Node Number 37

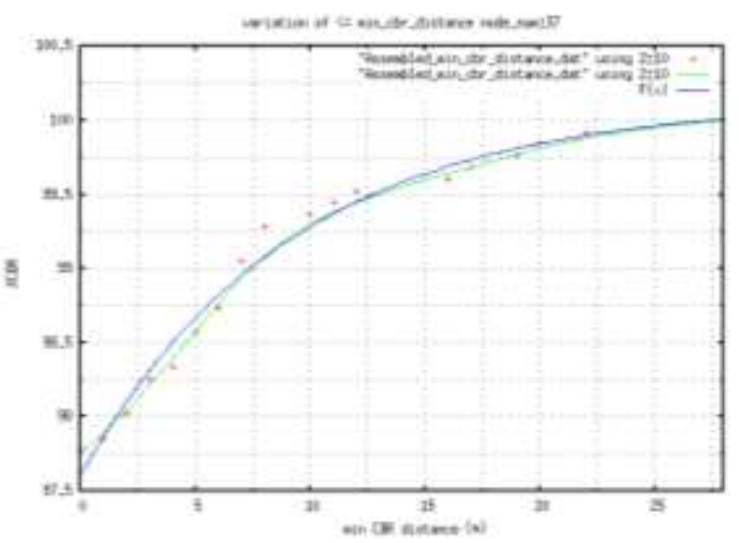

Figure 31: \% CBR $\leq$ min_CBR_distance: node_num 37 32. Node Number 38

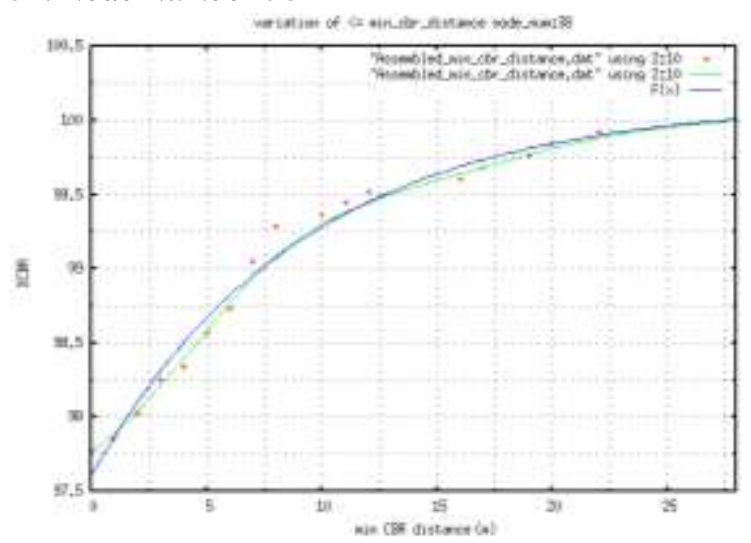

Figure 32: \% CBR $\leq$ min_CBR_distance: node_num 38 33. Node Number 39

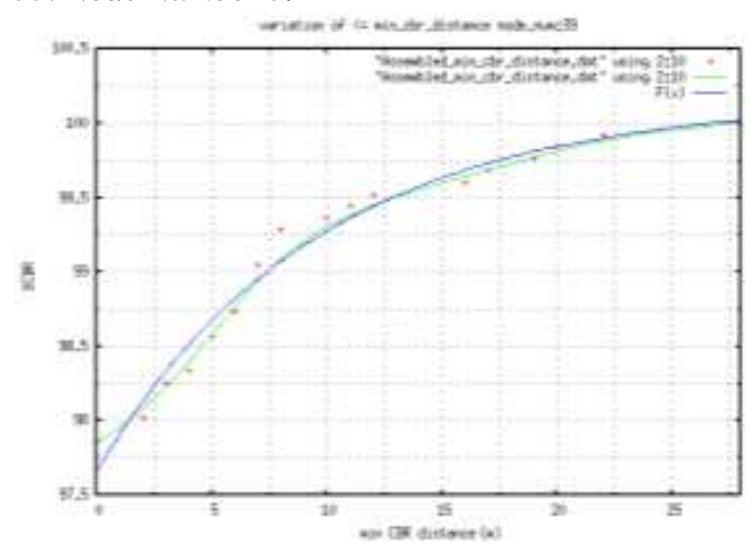

Figure 33: \% CBR $\leq$ min_CBR_distance: node_num 39 34. Node Number 40 
Proc. of Sixth International Conference On Advances in Computing, Electronics and Electrical Technology - CEET 2016 Copyright (C) Institute of Research Engineers and Doctors. All rights reserved.

ISBN no. 978-1-63248-109-2 doi: 10.15224/ 978-1-63248-109-2-10

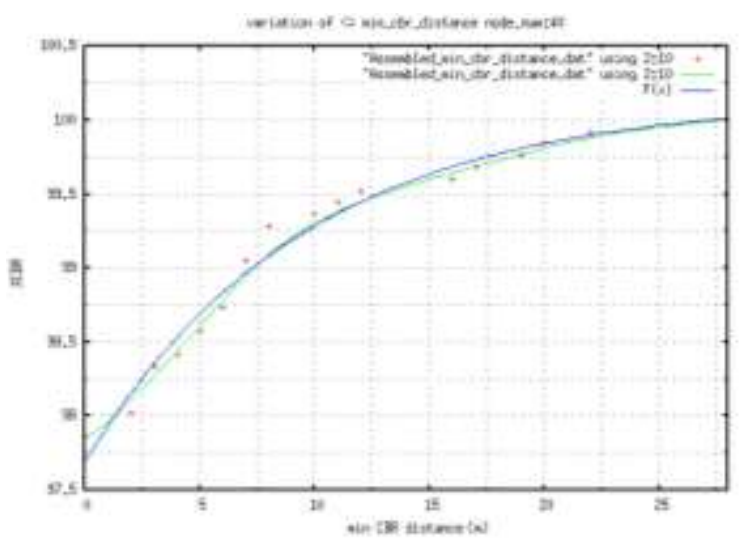

Figure 34: \% CBR $\leq$ min_CBR_distance: node_num 40 35. Node Number 41

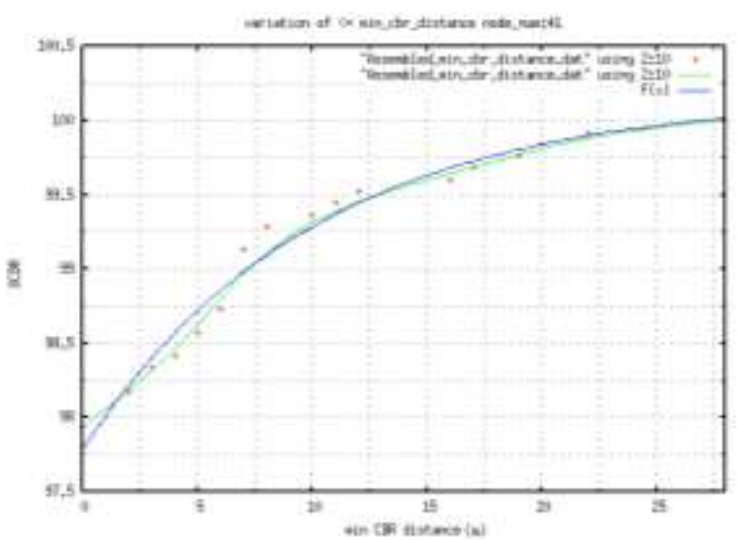

Figure 35: \% CBR $\leq$ min_CBR_distance: node_num 41 36. Node Number 42

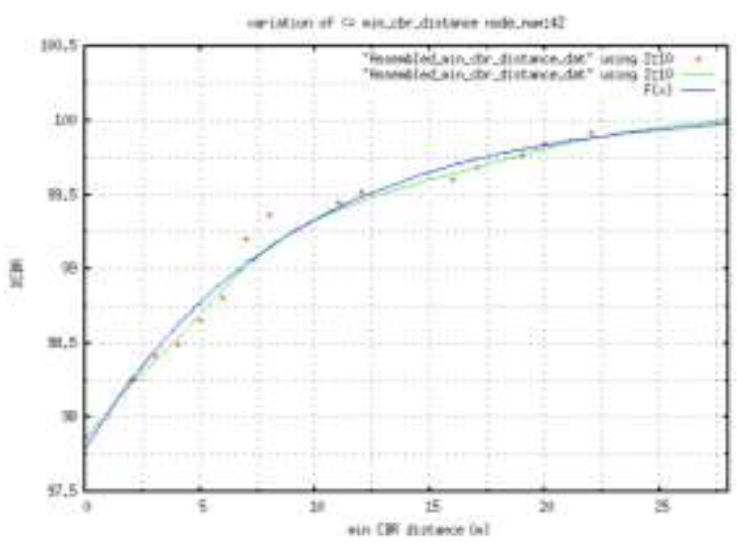

Figure 36: \% CBR $\leq$ min_CBR_distance: node_num 42 37. Node Number 43

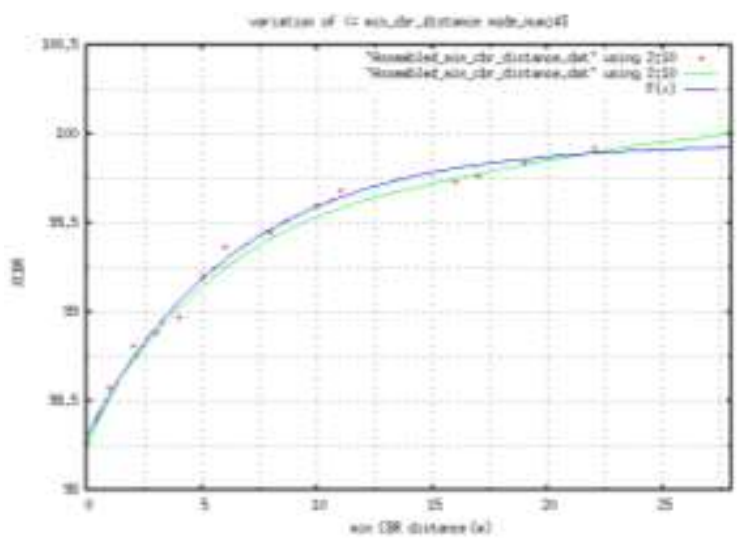

Figure 37: \% CBR $\leq$ min_CBR_distance: node_num 43 38. Node Number 44

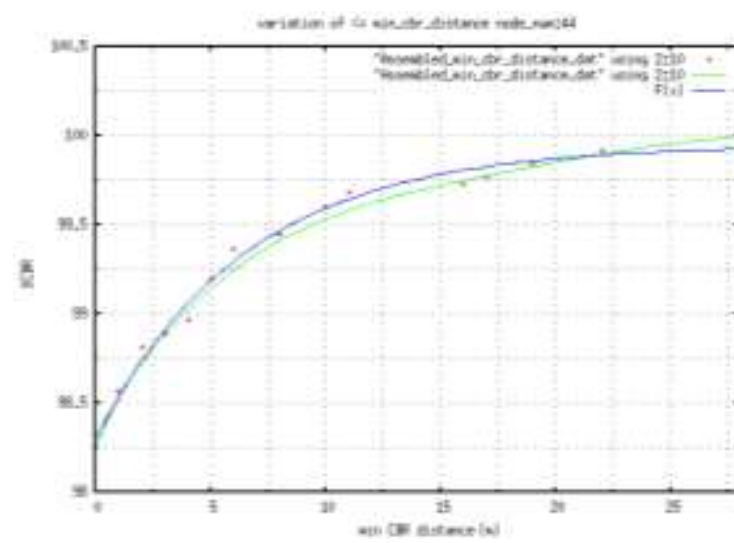

Figure 38: \% CBR $\leq$ min_CBR_distance: node_num 44 39. Node Number 45

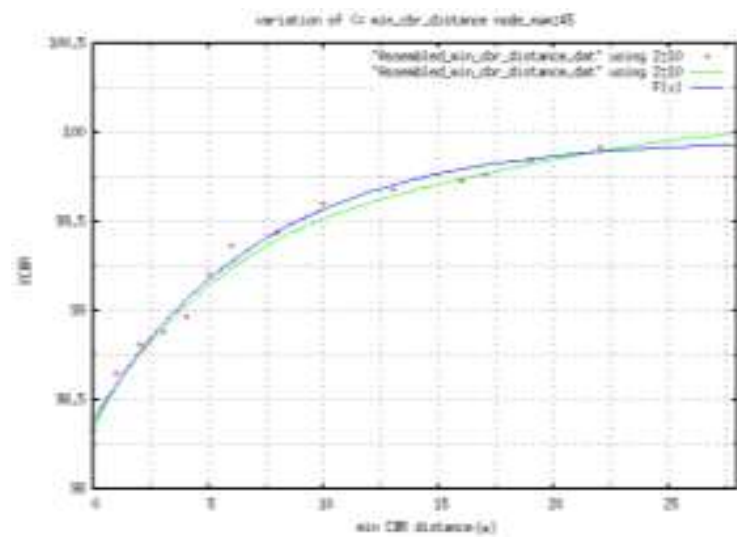

Figure 39: \% CBR $\leq$ min_CBR_distance: node_num 45 40. Node Number 46

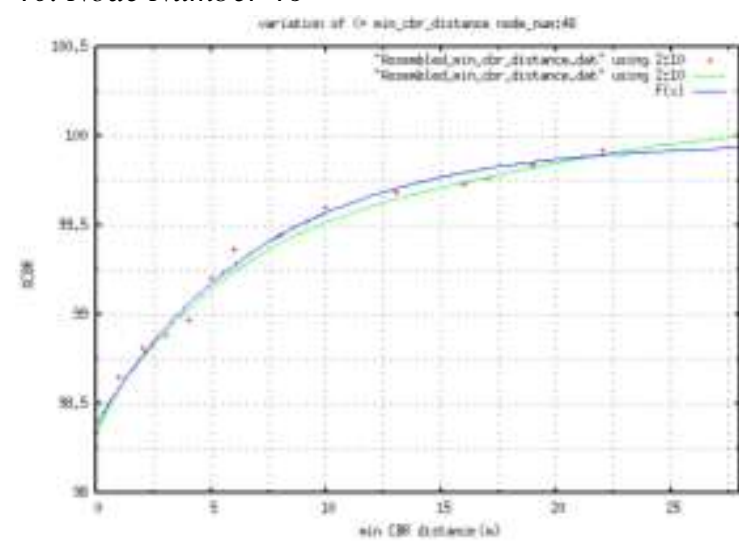

Figure 40: \% CBR $\leq$ min_CBR_distance: node_num 46 41. Node Number 47

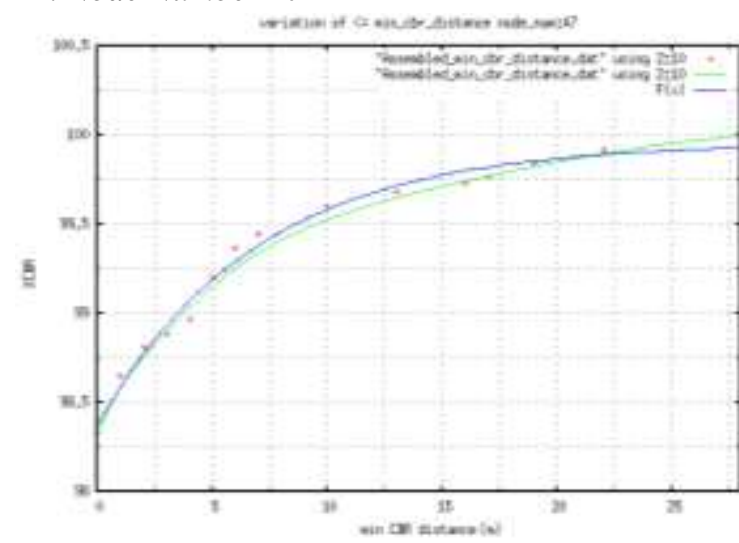

Figure 41: \% CBR $\leq$ min_CBR_distance: node_num 47 42. Node Number 48 
Proc. of Sixth International Conference On Advances in Computing, Electronics and Electrical Technology - CEET 2016 Copyright (C) Institute of Research Engineers and Doctors. All rights reserved.

ISBN no. 978-1-63248-109-2 doi: 10.15224/ 978-1-63248-109-2-10

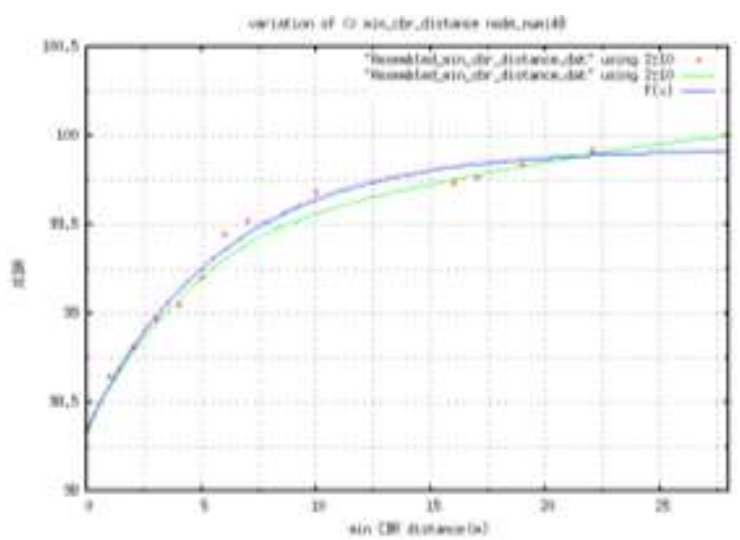

Figure 42: \% CBR $\leq$ min_CBR_distance: node_num 48 43. Node Number 49

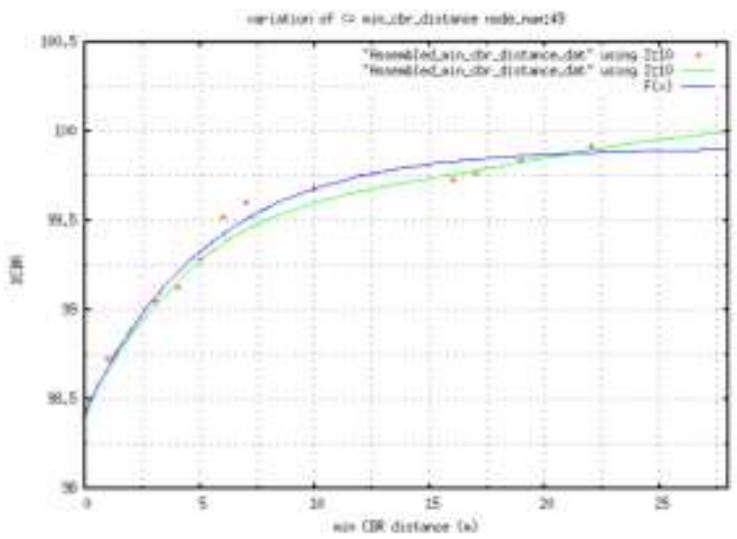

Figure 43: \% CBR $\leq$ min_CBR_distance: node_num 49 44. Node Number 50

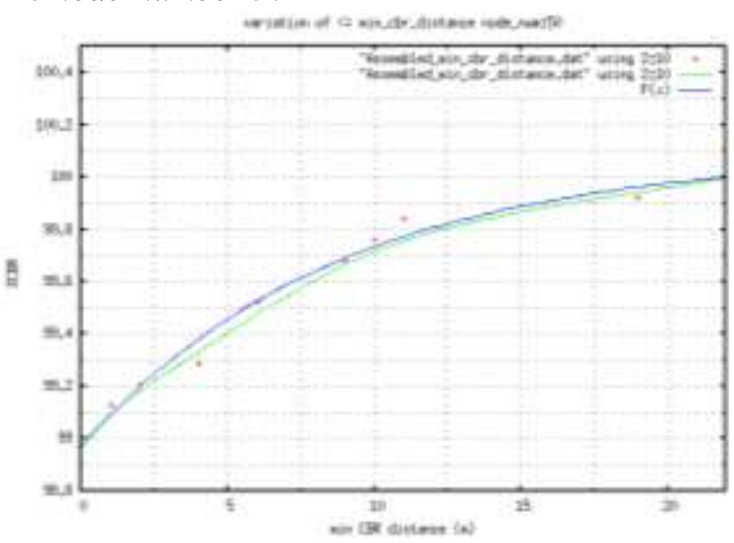

Figure 44: \% CBR $\leq$ min_CBR_distance: node_num 50 45. Node Number 51

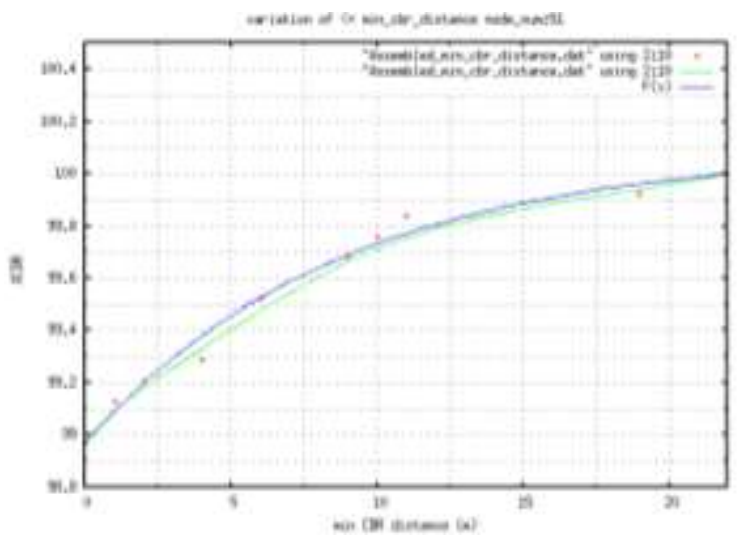

Figure 45: \% CBR $\leq$ min CBR distance: node_num 51 46. Node Number 52

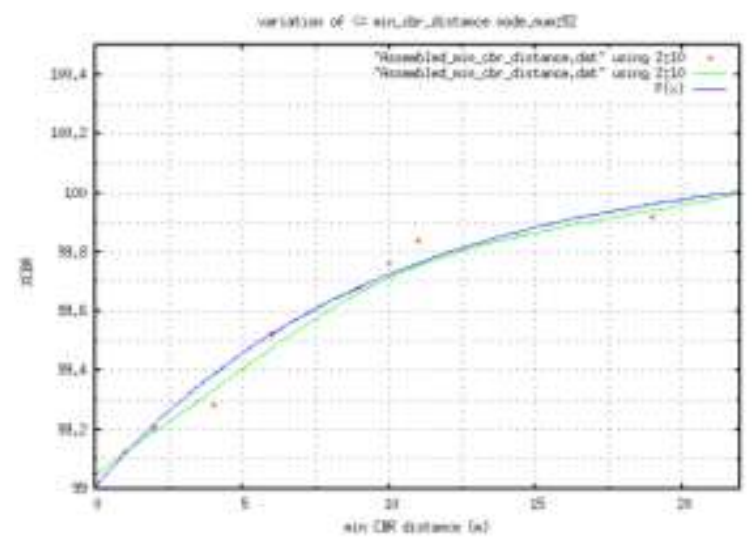

Figure 46: \% CBR $\leq$ min_CBR_distance: node_num 52 47. Node Number 53

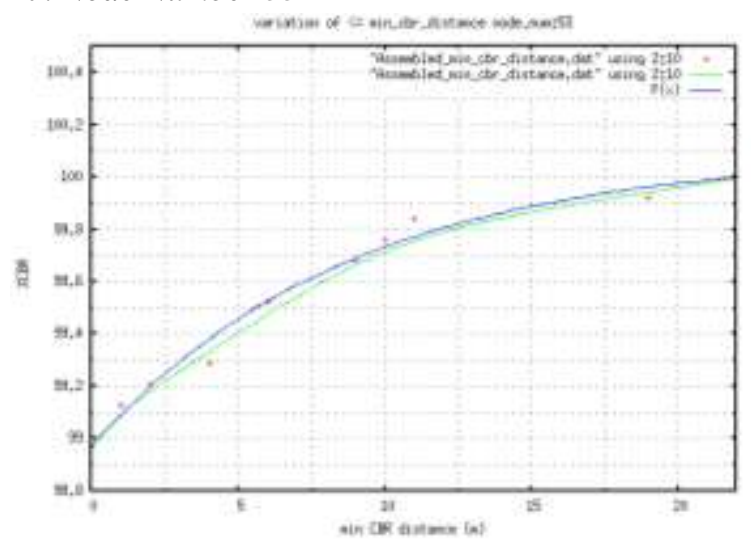

Figure 47: \% CBR $\leq$ min_CBR_distance: node_num 53 48. Node Number 54

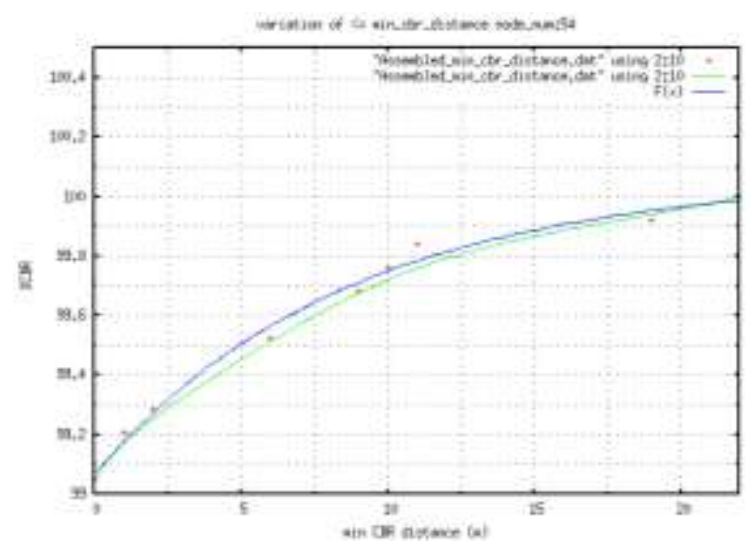

Figure 48: \% CBR $\leq$ min_CBR_distance: node_num 54 49. Node Number 55

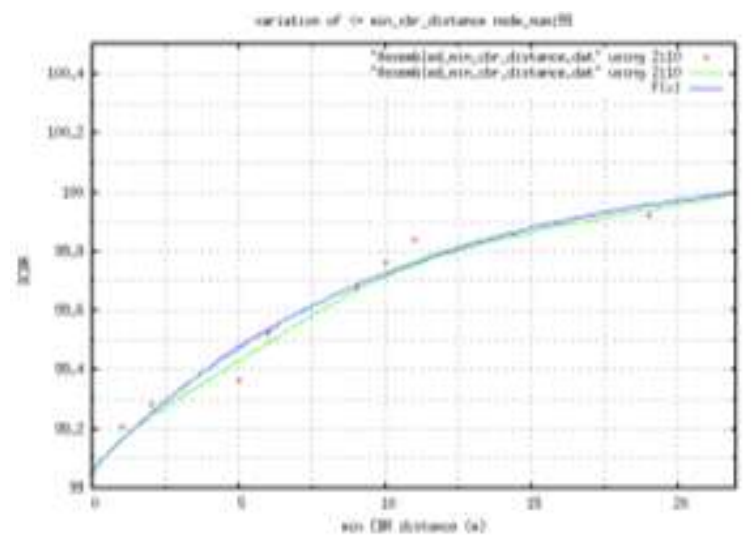

Figure 49: \% CBR $\leq$ min_CBR_distance: node_num 55 50. Node Number 56 


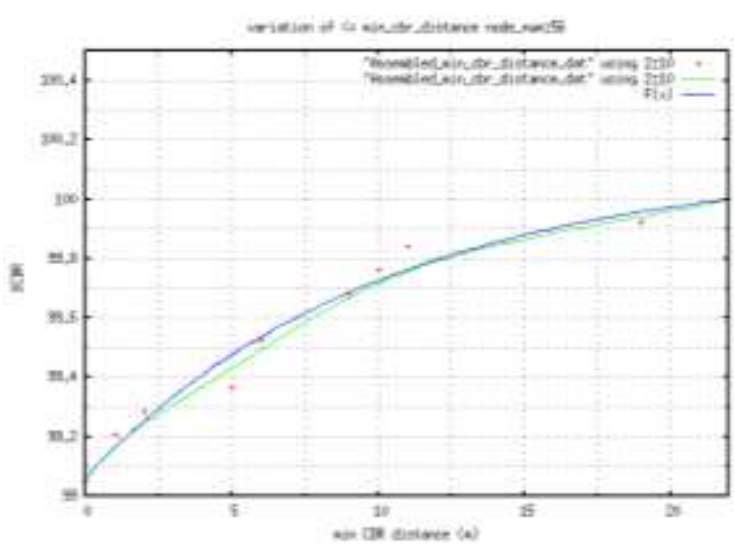

Figure 50: \% CBR $\leq$ min_CBR_distance: node_num 56

\section{Conclusion.}

This piece of study was aimed at studying another facet of distance coverage, rounded to nearest meter, by packets in ubicomp in situation of MANET transmission over varying Node densities. This work extends from a previous work [26, 27].

More precisely here, a metric Min_CBR_Dist, to assess the trend of minimum hop distance by packets in a ubicomp topography with varying node densities, has been developed. The experimental results presented here remain empirical based. The model put forward for cumulative \% CBR against Min_CBR_Dist is the exponential distribution model.

The assumptions stated in previous paper [21] hold, e.g availability of lightweight algorithms for locationaware transmission in mobile environments, lightweight MAUC OS supports for efficient binding/unbinding of MANET nodes and appropriate multi-threading/parallel communication in modules of MANET nodes.

The further work identified may include: trend analyses of parameters of equations for the model, formulating methods of predictability for metric Min_CBR_Dist and its trend and reporting observations of certain critical values identified. The purposes of this metric is also open for refinement together with its applicability in MANET transmission protocols. Development of further sub-component metrics for metric PPD remain desirable.

\section{References}

[1] M. Kaleem GALAMALI, Assoc. Prof Nawaz MOHAMUDALLY, Towards Dependable Pervasive Systems-A Position and Vision Paper, CEET 2014

[2] M. Kaleem GALAMALI, Assoc. Prof Nawaz MOHAMUDALLY, Model of Energy Savings achievable with Location-aware Node-to-Node Transmission in UbiComp , CEET 2014
[3] M. Kaleem GALAMALI, Assoc. Prof Nawaz MOHAMUDALLY, Model of Energy Savings achievable with Location-aware Node-to-Node Transmission in UbiComp Using Location Refresh Intervals, CEET 2014

[4] M. Kaleem GALAMALI, Assoc. Prof Nawaz MOHAMUDALLY, Model of Energy Savings achievable with Location-aware Transmission in UbiComp Using Relays, CEET 2014

[5] M. Kaleem GALAMALI, Assoc. Prof Nawaz MOHAMUDALLY, Mathematical modeling of need of exact number of relays to ensure seamless mobility in mobile computing, CEET 2014

[6] M. Kaleem GALAMALI, Assoc. Prof Nawaz MOHAMUDALLY, Modelling of need for multiple relays for ensuring seamless mobility, CEET 2014

[7] M. Kaleem GALAMALI, Assoc. Prof Nawaz MOHAMUDALLY, Investigation of prominence of placements of relays in a ubicomp topography,

[8] M. Kaleem GALAMALI, Assoc. Prof Nawaz MOHAMUDALLY, Model of energy savings achievable with location-aware transmission in ubicomp using optimised number of relays.

[9] M. Kaleem GALAMALI, Assoc. Prof Nawaz MOHAMUDALLY, Investigation of Prominence of Placements of Optimised Number of Relays in a Ubicomp Topography using Location-Aware Transmission, CEET 2015.

[10] M. Kaleem GALAMALI, Assoc. Prof Nawaz MOHAMUDALLY, Extending Node Battery Availability in Ubicomp with Location-Aware Transmission, CEET 2015.

[11] M. Kaleem GALAMALI, Assoc. Prof Nawaz MOHAMUDALLY, Extending Node Battery Availability in Ubicomp with Location-Aware Transmission using Location Refresh Intervals, CEET 2015.

[12] M. Kaleem GALAMALI, Assoc. Prof Nawaz MOHAMUDALLY, Extending Node Battery Availability in Ubicomp with Location-Aware Transmission using Uniformly Placed Relays, CEET 2015.

[13] M. Kaleem GALAMALI, Assoc. Prof Nawaz MOHAMUDALLY, Extending Node Battery Availability in Ubicomp with Location-Aware Transmission Using Optimally Placed Relays, CEET 2015.

[14] M. Kaleem GALAMALI, Assoc. Prof Nawaz MOHAMUDALLY, Model of Sender Node Energy Savings Achievable with Location-Aware MANET Transmission in Ubicomp. ACCN 2016

[15] M. Kaleem GALAMALI, Assoc. Prof Nawaz MOHAMUDALLY, Model of Overall Node Energy Savings Achievable with Location-Aware MANET Transmission in Ubicomp. ACCN 2016

[16] M. Kaleem GALAMALI, Assoc. Prof Nawaz MOHAMUDALLY, Model of Sender Node Extra Energy Savings Achievable in MANET Against Direct Node-toNode Transmission Using Location-Aware Transmission in Ubicomp. ACCN 2016

[17] M. Kaleem GALAMALI, Assoc. Prof Nawaz MOHAMUDALLY, Model of Overall Node Extra Energy Savings Achievable in MANET against Direct Node-toNode Transmission Using Location-Aware Transmission in Ubicomp. ACCN 2016

[18] M. Kaleem GALAMALI, Assoc. Prof Nawaz MOHAMUDALLY, Model of Energy Consumption Ratio Achievable in MANET Using Location-Aware Transmission in Ubicomp. ACCN 2016

[19] M. Kaleem GALAMALI, Assoc. Prof Nawaz MOHAMUDALLY, Model of Minimum Energy Consumption Ratio Achievable in MANET Using LocationAware Transmission in Ubicomp. ACCN 2016

[20] M. Kaleem GALAMALI, Assoc. Prof Nawaz MOHAMUDALLY, Model of Maximum Energy Consumption Ratio Achievable in MANET Using LocationAware Transmission in Ubicomp. ACCN 2016

[21] M. Kaleem GALAMALI, Assoc. Prof Nawaz MOHAMUDALLY, Model of Overall Energy Consumption Fairness Ratio Achievable in MANET Using LocationAware Transmission in Ubicomp. ACCN 2016 
[22] M. Kaleem GALAMALI, Assoc. Prof Nawaz MOHAMUDALLY, Model of Overall Energy Consumption Fairness Proportion Achievable in MANET Using LocationAware Transmission for Ubicomp.

[23] M. Kaleem GALAMALI, Assoc. Prof Nawaz MOHAMUDALLY, Model of Minimum Fairness Proportion Achievable in MANET Using Location-Aware Transmission for Ubicomp.

[24] M. Kaleem GALAMALI, Assoc. Prof Nawaz MOHAMUDALLY, Model of Maximum Fairness Proportion Achievable in MANET Using Location-Aware Transmission for Ubicomp.

[25] M. Kaleem GALAMALI, Assoc. Prof Nawaz MOHAMUDALLY, Model of Sender Fairness Proportion Achievable in MANET Using Location-Aware Transmission for Ubicomp.

[26] M. Kaleem GALAMALI, Assoc. Prof Nawaz MOHAMUDALLY, Model of Distance Travelled by packets in MANETs using Location-Aware Transmission for Ubicomp.

[27] M. Kaleem GALAMALI, Assoc. Prof Nawaz MOHAMUDALLY, Model of Maximum CBR Distance Travelled by packets in MANETs using Location-Aware Transmission for Ubicomp.

[28] Markus Bylund and Zary Segall, Towards seamless mobility with personal servers, 2004

[29] Masugi Inoue, Mikio Hasegawa, Nobuo Ryoki and Hiroyuki Morikawa, Context-Based Seamless Network and Application Control, 2004

[30] Xiang Song, Umakishore Ramachandran, MobiGo: A Middleware for Seamless Mobility, College of Computing Georgia Institute of Technology, Atlanta, GA, USA, August 2007

[31] Budzisz, Ferrús, R., Brunstrom A., Grinnemo, K, Fracchia, R., Galante, G., and Casadevall, F. Towards transport-layer mobility: Evolution of SCTP multihoming, March 2008

[32] Paul Dourish \& Genevieve Bell, Divining a digital future, 2011.

[33] Xiang Song, Seamless Mobility In Ubiquitous Computing Environments, PhD Thesis, Georgia Institute of Technology, August 2008

[34] Kevin O Mahony, Jian Liang, Kieran Delaney, User-Centric Personalization and Autonomous Reconfiguration Across Ubiquitous Computing Environments, NIMBUS Centre Cork Institute of Technology, Cork, Ireland, UBICOMM 2012

[35] Pablo Vidales, Seamless mobility in 4G systems, Technical Report, University of Cambridge, Computer Laboratory, Number 656, November 2005

[36] João Pedro Sousa and David Garlan, Aura: An Architectural Framework for User Mobility in Ubiquitous Computing Environments, School of Computer Science, Carnegie Mellon University, USA, August 2002

[37] Dennis Lupiana, Ciaran O’Driscoll, Fredrick Mtenzi, Defining Smart Space in the Context of Ubiquitous Computing, Dublin Institute of Technology, Ireland, Special Issue on ICIT 2009 Conference - Web and Agent Systems, 2009

[38] N.S.V.Shet1, Prof.K.Chandrasekaran2 and Prof. K.C.Shet3, WAP Based Seamless Roaming In Urban Environment with Wise Handoff Technique, International Journal of UbiComp (IJU), Vol.1, No.4, October 2010

[39] Yipeng Yu Dan He Weidong Hua Shijian Li Yu Qi Yueming Wang Gang Pan, FlyingBuddy2: A Braincontrolled Assistant for the Handicapped, Zhejiang University, UbiComp'12, September 5-8, 2012.

[40] Jing Su, James Scott, Pan Hui, Jon Crowcroft, Eyal de Lara Christophe Diot, Ashvin Goel, Meng How Lim, and Eben Upton, Haggle: Seamless Networking for Mobile Applications, 2007

[41] Rui Han, Moustafa M. Ghanem, Li Guo, Yike Guo*, Michelle Osmond, Enabling cost-aware and adaptive elasticity of multi-tier cloud applications, Future Generation Computer Systems, 2012

[42] Byrav Ramamurthy, K. K. Ramakrishnan, Rakesh K. Sinha, Cost and Reliability Considerations in Designing the NextGeneration IP over WDM Backbone Networks, 2012.

[43] Bhavish Aggarwal, Aditya Akella, Ashok Anand, Athula Balachandran, Pushkar Chitnis, Chitra Muthukrishnan, Ram
Ramjee and George Varghese, EndRE: An End-System Redundancy Elimination Service for Enterprises, NSDI 2010, San Jose, CA

[44] Ashok Anand, Vyas Sekar and Aditya Akella, SmartRE: An Architecture for Coordinated Network-wide Redundancy Elimination, SIGCOMM 2009, Barcelona, Spain

[45] John Breeden II, "Smart-phone battery life could double without better batteries", Nov 14, 2012

[46] Andy Boxall, "When will your phone battery last as long as your kindle", December 5, 2012

[47] Imielinski, T. and Navas, J.C. (1999). GPS-based geographic addressing, routing, and resource discovery. Comms. ACM Vol. 42, No. 4, pp. 86-92.

[48] Hightower, J. and Borriello, G. (2001). Location Systems for Ubiquitous Computing. IEEE Computer, Vol. 34, No. 8, August, pp. 57-66.

[49] Harter, A., Hopper, A., Steggles, P., Ward, A. and Webster, P. (2002). The Anatomy of a Context-Aware Application. Wireless Networks, Vol. 8, No. 2-3, Mar-May, pp. 187-197.

[50] Hightower, J., Brumitt, B. and Borriello, G. (2002). The Location Stack: A Layered Model for Location in Ubiquitous Computing. Proceedings of the 4th IEEE Workshop on Mobile Computing Systems \& Applications (WMCSA 2002), Callicoon, NY, USA, June, pp. 22-28.

[51] Graumann, D., Lara, W., Hightower, J. and Borriello, G. (2003). Real-world implementation of the Location Stack: The Universal Location Framework. Proceedings of the 5th IEEE Workshop on Mobile Computing Systems \& Applications (WMCSA 2003), Monterey, CA, USA, October. pp. $122-128$

[52] Ko, Y., \& Vaidya, N. H. (2000). Location-aided routing (LAR) in mobile ad hoc networks. Wireless Networks, 6(4), 307-321.

[53] Liao, W.-H., Tseng, Y.-C., \& Sheu, J.-P. (2001). GRID: a fully location-aware routing protocol for mobile ad hoc networks. Telecommunication Systems, 18(1), 37-60.

[54] Kuhn, F., Wattenhofer, R., Zhang, Y., \& Zollinger, A. (2003). Geometric ad-hoc routing: of theory and practice. In Proceedings of the ACM (PODC'03) (pp. 63-72).

[55] Jiang, X., \& Camp, T. (2002). Review of geocasting protocols for a mobile ad hoc network. In Proceedings of the Grace Hopper Celebration (GHC).

[56] Ko, Y. \& Vaidya, N. H. (1999). Geocasting in mobile ad hoc networks: location-based multicast algorithms. In Proceedings of the IEEE (WMCSA '99) (pp. 101).

[57] Mauve, M., Fuler, H., Widmer, J., \& Lang, T. (2003) Position-based multicast routing for mobile ad-hoc networks (Technical Report TR-03-004). Department of Computer Science, University of Mannheim.

[58] Xu, Y., Heidemann, J., \& Estrin, D. (2001). Geographyinformed energy conservation for adhoc routing. In Proceedings of the ACM/IEEE (MOBICOM'01) (pp. 70-84).

[59] Hu, Y.-C., Perrig, A., \& Johnson, D. (2003). Packet leashes: a defense against wormhole attacks in wireless ad hoc networks. In Proceedings of the INFOCOM' 03 (pp. 19761986).

[60] Patwari, N., Hero III, A. O., Perkins, M., Correal, N. S., \& O'Dea, R. J. (2003). Relative location estimation in wireless sensor networks. IEEE Transactions on Signal Processing, 51(8), 2137-2148

[61] Baldauf, M., Dustdar, S., \& Rosenberg, F. (2007). A Survey on Context Aware Systems. International Journal of Ad Hoc and Ubiquitous Computing, Inderscience Publishers. forthcoming. Pre-print from: http://www.vitalab.tuwien.ac.at/ florian/ papers/ijahuc2007.pdf

[62] Hong, D., Chiu, D.K.W., \& Shen, V.Y. (2005) Requirements elicitation for the design of context-aware applications in a ubiquitous environment. In Proceedings of 
Proc. of Sixth International Conference On Advances in Computing, Electronics and Electrical Technology - CEET 2016 Copyright (C) Institute of Research Engineers and Doctors. All rights reserved.

ISBN no. 978-1-63248-109-2 doi: 10.15224/ 978-1-63248-109-2-10

ICEC'05 (pp. 590-596).

[63] Neeraj Tantubay, Dinesh Ratan Gautam and Mukesh Kumar Dhariwal, A Review of Power Conservation in Wireless Mobile Ad hoc Network (MANET)", International Journal of computer Science Issues, Vol 8, Issue 4, No 1, July 2011.

[64] Wenrui Zhao, Mostafa Ammar and Ellen Zegura, "A Message Ferrying Approach for Data Delivery in Sparse Mobile Ad Hoc Networks", MobiHoc'04, May 24-26, 2004, Roppongi, Japan.

About Author (s):

Associate Professor Nawaz Mohamudally works at University of Technology, Mauritius (UTM) and has undertaken supervision of MPhil/PhD Students for many years.

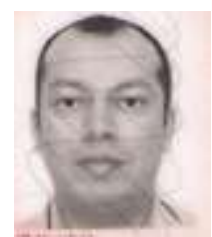

M. Kaleem Galamali is a part-time student (achieved M Phil Transfer on 28.10.2014, currently PhD student) at UTM under supervision of A.P. Nawaz Mohamudally. 